\title{
The U.S. Geological Survey Energy Resources Program
}

The USGS Energy Resources Program provides impartial, scientifically robust information to advance the understanding of geologically based energy resources, to contribute to plans for a secure energy future, and to facilitate evaluation and responsible use of resources.
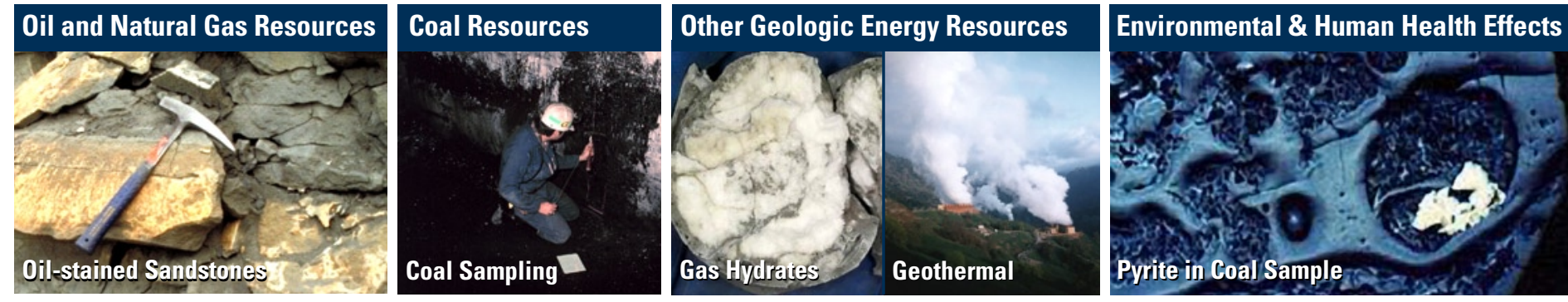

\section{The Need for Geologic Energy Resources Information}

The United States uses tremendous amounts of geologic energy resources. In 2004 alone, the United States consumed more than 7.4 billion barrels of oil, 21.9 trillion cubic feet of natural gas, and 1.1 billion short tons of coal. Forecasts indicate the Nation's need for energy resources will continue to grow, raising several questions:

- How much domestic and foreign petroleum resources are available to meet the growing energy demands of the Nation and world?
- Does the United States have coal deposits of sufficient quantity and quality to meet demand over the next century?

- What other geologic energy resources can be added to the U.S. energy mix?

- How do the occurrence and use of energy resources affect environmental quality and human health?

Mallik drilling site, located on the Mackenzie Delta in the Northwest Territories, Canada. The Mallik Project developed the first production test well for gas hydrates.

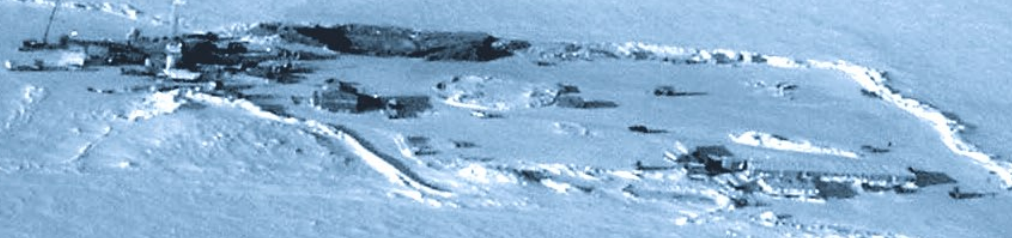

Unbiased information from robust scientific studies is needed for sound energy policy and resource management decisions addressing these issues

\section{The USGS Energy Resources Program Addresses This Need}

The U.S. Geological Survey (USGS) Energy Resources Program (ERP) provides information from impartial, comprehensive research investigations of geologic energy resources, including: petroleum (oil, natural gas, natural gas liquids), coal, gas hydrates, geothermal resources, oil shale, oil sands, uranium, and heavy oil and natural bitumen. This information advances the understanding of geologic processes and the economic, technical, and environmental factors affecting energy resource occurrence, availability, and recoverability. An improved understanding facilitates the development of sound policies on domestic and foreign energy resources, and the responsible management of energy resources on Federal lands. The ERP has a clearly defined role:

\section{Program Mission---}

(1) to advance the understanding of processes affecting the formation, accumulation, occurrence, and alteration of geologically based energy resources;

(2) to conduct scientifically robust assessments of onshore and state offshore U.S. energy resources (pre-development) and international energy resources;

(3) to study environmental and human health effects associated with energy resource occurrence, production, and use.
To fulfill this unique role, the ERP supports a research portfolio that is responsive to national and regional priorities, including those established through legislative directives such as the Energy Policy Act of 2005, internal strategic planning, and customer surveys and needs. Primary consumers of information and products from this research portfolio include the U.S. Congress, the Department of the Interior land and resource management Bureaus, other Federal, State and local agencies, nongovernmental organizations, the energy industry, academia, foreign organizations and the general public. 
analyses, stratigraphic and lithologic information, geologic maps, geophysical logs, and bibliographic references on oil shale geology.

- Gas hydrates represent an immense energy resource underlying large portions of the world's marine continental shelves and Arctic continental areas. The USGS participates in several international consortia of research, industry, and academic institutions - most recently in India. Previously, the Mallik Research Consortium drilled three test wells in Canada's Mackenzie Delta, and the results, demonstrating the producibility of this en-
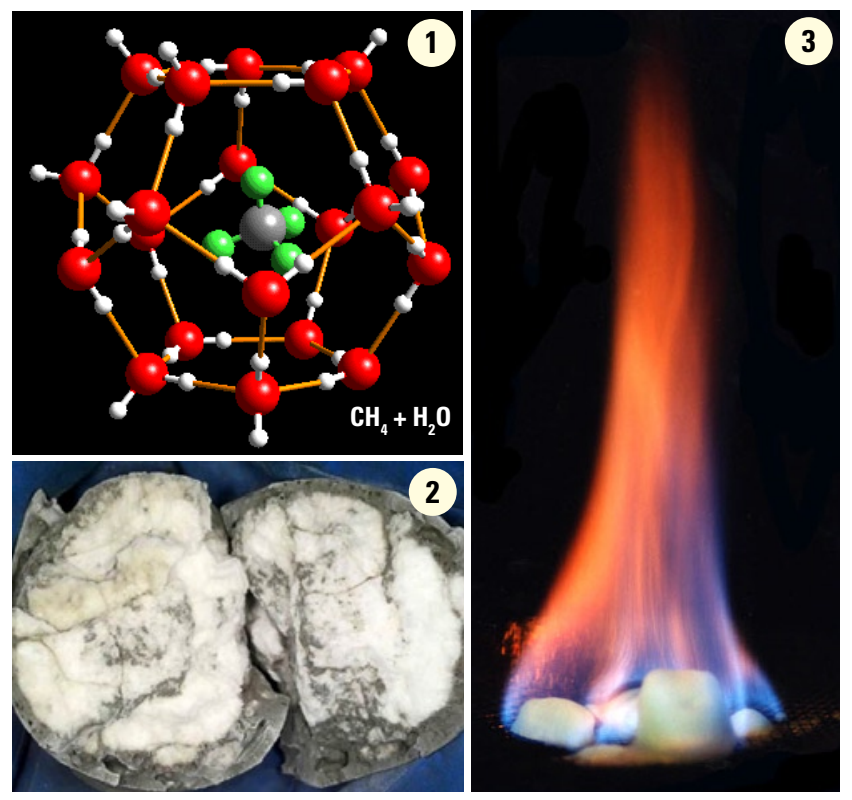

1) A molecular model depicts the cage-like structure of gas hydrate, showing the association between water (red and white) and methane (green and gray). 2) This drill core sample shows that gas hydrates in nature appear as white, ice-like, crystalline solids. 3) These solids can be decomposed to release methane, which can be burned to provide a source of energy.

ergy resource, were published in 2005.

The USGS also has ongoing cooperative research efforts with the BLM, Minerals Management Service, State of Alaska, Department of Energy, industry, and Native Alaskan corporations to further the understanding of gas hydrate endowment and recoverability from Alaska's North Slope.

- The USGS is studying geothermal energy resources in the western United States. The objectives are to produce a detailed estimate of electric power generation potential, and evaluate the major technological challenges and environmental effects of increased use of geothermal resources.

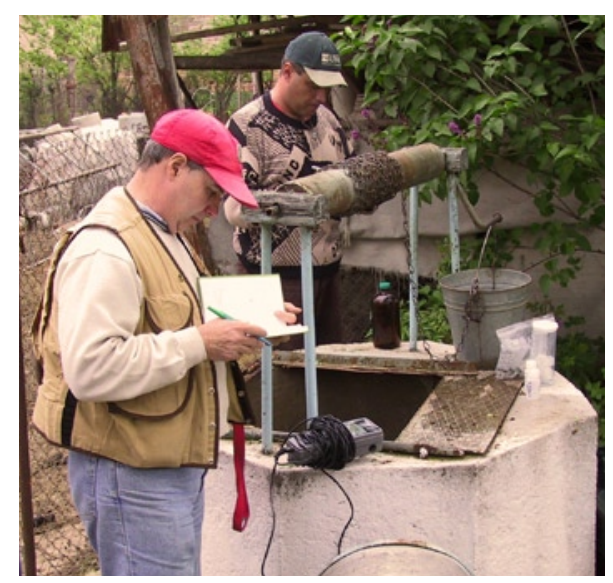

USGS scientists collect samples from a water well in central Europe to investigate a possible connection among drinking water, coal, and deleterious human health effects in the region.

\section{Environmental and Human Health Effects}

Energy resource commodities such as coal, oil, and natural gas contain toxic substances that, if mobilized, may adversely affect human health and the environment. The USGS is conducting research to address the linkages among geology, energy resources, and human health. This information will enable land managers and environmental and medical officials to better assess human health and ecosystem effects, develop cost-effective remedies, and establish appropriate policies and regulations.

\section{Examples:}

- USGS scientists are investigating the legacy effects of historical oil and gas development operations, and the environmental and human health impacts of coal extraction, coal combustion, and coalbed methane production. Information from these efforts is used to address a suite of issues including coal combustion by-products, mine drainage and produced water disposal.

- The USGS has research partnerships with U.S. and international health organizations to study areas with documented health issues, including several Balkan countries in central Europe. These efforts are addressing how the occurrence of energy resources may give rise to adverse health effects, and what measures can be taken to mitigate exposure. The information gained from these collaborations is being applied in the United States, where USGS scientists are investigating rural areas for possible connections among coal, drinking water supplies, and rates of disease.

\section{Digital Data and Websites}

\section{http://energy.usgs.gov}

All recent USGS ERP products are available to the general public in digital format, including:

- National Oil and Gas Assessments http://energy.cr.usgs.gov/oilgas/noga/

- World Energy Project http://certmapper.cr.usgs.gov/rooms/we/ index.jsp

- Organic Geochemistry Database (over 65,000 records of analyses of crude oil, natural gas and rock samples from locations worldwide) http://energy.cr.usgs.gov/prov/og/

- USGS Produced Waters Database (contains locations and major ion compositions of waters pumped to the surface during oil and gas production) http://energy.cr.usgs.gov/prov/prodwat/

- National Petroleum Reserve, Alaska Legacy Data Archive (contains seismic and well log data) http://nerslweb.cr.usgs.gov/

\section{For more information, please contact:}

Brenda Pierce, Program Coordinator Energy Resources Program

U.S. Geological Survey, MS 915A

Reston, VA 20192

Telephone: (703) 648-6470

Email: bpierce@usgs.gov

James L. Coleman, Chief Scientist Eastern Energy Resources Team Reston, VA

Email: jlcoleman@usgs.gov

Ed Johnson, Acting Chief Scientist Central Energy Resources Team

Denver, CO

Email: ejohnson@usgs.gov

Ken Bird, Program Representative Western Earth Surface Processes Team Menlo Park, CA

Email: kbird@usgs.gov

Or visit the websites at: http://energy.usgs.gov http://www.usgs.gov 